\title{
LOOSING AGRICULTURAL HERITAGE IN RURAL LANDSCAPES - A CASE STUDY IN KOPPÁNY VALLEY AREA, HUNGARY
}

\author{
Géza Gelencsér, Márton Vona, Csaba Centeri
}

Received 21 July 2011; Accepted 23 March 2012

\begin{abstract}
The research is focusing on the Big Koppány stream (Hungary), which is designated by local communities as an experimental area for agro-ecological development. This poverty stricken, underdeveloped area is showing symptoms of continuous ecological deterioration (typical in many areas of Hungary and Europe). We introduce the partly surviving agri-cultural heritage of the area. We also introduce Vox Valley Development Association who is decided to demonstrate the possible actions which help the formation of a sustainable agro-ecological system. This paper concentrates on proposals which will help the evolution of such a system.
\end{abstract}

Key words: agro-ecological development, agri-cultural heritage, EU rural development funds, biodiversity, local residents

\begin{abstract}
Absztrakt:A mezőgazdaság kulturális örökségének elvesztése a vidéki tájban esettanulmány a Koppány-völgyből. A kutatás a Nagy Koppány folyó részterületére koncentrál, melyet a helyi közösségek kutatási területté nyilvánítottak agro-ökológiai fejlesztések céljából. Ez a szegénység sújtotta, fejletlen terület a folyamatos ökológiai hanyatlás jeleit mutatja (Magyarország és Európa számos területén jellemző). Ismertetjük a területen részben fennmaradt mezőgazdasági kulturális örökséget. Bemutatjuk a Völgy Hangja Fejlesztési Társaságot is, amely elhatározta, hogy szemlélteti a lehetséges lépéseket, amelyek egy fenntartható agroökológiai rendszer kialakításához szükségesek. Cikkünk olyan javaslatokra koncentrál, amelyek segítik az ilyen rendszerek kifejlődését.
\end{abstract}

Kulcsszavak: agro-ökológiai fejlesztés, mezőgazdasági kulturális örökség, EU vidékfejlesztési alap, biodiverzitás, helyi lakosok

\section{Introduction}

Regardless of socialist will to force people from farms to live in bigger cities, $87 \%$ of the area, $47 \%$ of the population and $96 \%$ of the settlements of Hungary is qualified as rural ${ }^{1}$ (http 1 ). Within this category there are huge differences in terms of ageing and decrease of local population and poverty as a result of so called "wild capitalism". Most of the critical literature has engaged in a critique of the resulting socio-spatial and socio-economical inequalities rendered by the end of Soviet Regime (Gowan 1995, Pickles and Smith 1998, Humphrey 2002, Rainnie

\footnotetext{
${ }^{1}$ www.ecovast.hu/umvp1.doc
} 
et al. 2002). There is large diversity of landscapes characteristic for specific regions (Wascher, 2004) and this diversity is one of the key cultural-heritage elements for Hungary just as well for Europe. Nearly two thirds of the rural areas are lagging behind, which is not a Hungarian specialty (North and Smallborne 2000); and the gap is constantly growing between developed and underdeveloped areas (Palang et al. 2006). In general poverty and decreasing population show negative correlation with the size of the settlements and positive correlation with the density of settlements and the distance from Budapest and the county centres (Decree No. 137/2004. (IX. 18.) of the Ministry of Agriculture, 2004). In these poorer areas agricultural enterprises are dominant (cf. figure 1) and the access to public services is limited (cf. figure 2). There is a tendency for regional differences to disappear because of the rural exodus (Douglass, 1974; Shaw, 1974, 1975; Arizpe, 1981; Symes, 1993, Karcagi-Kovács et al., 2009) of people from these remote settlements.

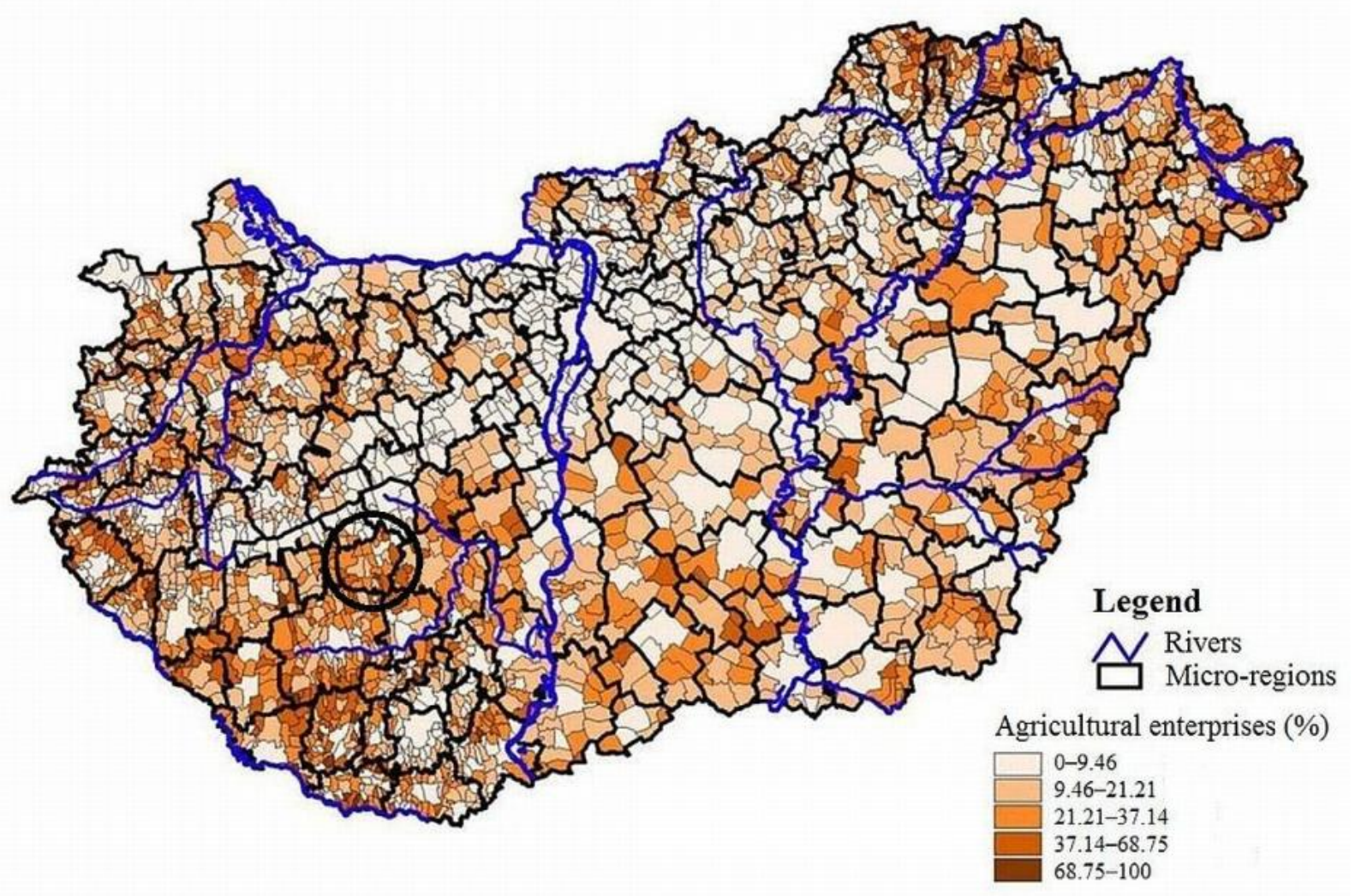

Fig 1. Percentage of agricultural enterprises in Hungary by micro-regions (the examined region in black circle).

To fully understand the significance of agricultural heritage it is important to skip the commonly used nostalgic and romantic approaches and the assessment of cultural values and to focus on the upcoming effects of the most threatening global trends: climate change; food, potable water and fossil fuel supply crises as well as biodiversity loss. It is easier to explain for locals what agricultural or rural heritage is with the following description: "a spectrum of well tested solutions to local challenges and problems", and in a more simple way: "a collection of local recipes to survive", which, apart from their cultural values, can help us to create an ecologically and socially more healthy rural life, a sustainable local eco-social system. 




Fig 2. Access to public services in Hungary by micro-regions (the examined region in black circle, otherwise thicker black lines are county limits).

\section{Description and history of the examined area}

Koppány Valley is a hilly (loess) micro region situated in South-Transdanubia and consists of 15 small, underdeveloped villages in the watershed of the Koppány-stream, with an average population of 250 today (reaching 1000 before World War II). The valley had been continuously inhabited since the Mesolithic age. Data from the $19^{\text {th }}$ and the first half of the $20^{\text {th }}$ centuries show a very diverse local agriculture with livestock, cereals, corn, tobacco, hemp, fruit and wine as main crops (Szerényi, 2001; Molnár, 1996; Fiar and Izsák, 1997; Mari, 1997; Metzger, 1997; Nagy, 1997; Rédei et al., 1998; Szabó and Ruprecht, 2001; Tóth, 2001; Tóth, 2008; Tatár et al., 2009; Renes et al. 2010).

Although these villages suffered many shocks in the course of the history - as Hungary was serving as a buffer zone against Eastern invaders - but none of them was as elementary and devastating as the socialist collectivisation', the so called 'cooperative' era following the transformation of the traditional agricultural sector into state farms and cooperatives after the second World War. It imposed a really heavy 'rural heritage' on the countryside which is still alive, and it is one of the main factors hindering poorer regions in their development (Toma et al., 2010).

These state coops had been operated by the simplest binary code of producing more until the early 1990s, and this productivist ideology had caused major changes and damages in the environment and in the society. The environment and the rural society had to adapt to the intensification of the agricultural production, which meant creating bigger plot sizes by eliminating zonal habitats (fences, tree rows, etc), using chemicals and mostly applying monoculture in crop production.

After the change of the regime, in the early 1990s, a partial compensation scheme was introduced. It was based on "compensation vouchers" given to former land owners or their relatives, who could participate in auctions. However it only boosted speculation, and in the Koppany-valley it resulted in the decline of animal husbandry and in the former cooperative leaders and other external investors then holding $85-95 \%$ of the arable area of the region.

\footnotetext{
${ }^{2}$ http://real.mtak.hu/506/1/38206_ZJ1.pdf
} 
The area now is showing symptoms of continuous social, economic and ecological deterioration that are typical in many other areas of the post socialist countries, such as rural exodus, ageing, weak civil sphere, lack of entrepreneurs, shrinking ecological habitats, diffuse contamination of surface waters by agricultural chemicals etc.

Remaining local cope with saving the remaining cultural heritage or part of the cultural values in folklore dancing clubs, participating on national holiday programs; on photo exhibitions where photos of former agricultural buildings, agricultural landscapes and some landscape elements (e.g. crosses with Christ etc.) are shown. Cultural values of the area, folk poetry, folk songs and even children's games are described by Együd (1975, 1978, 1981a, 1981b), Szapu (1999) and Kapitány \& Imrö (2001).

\section{Symptoms of social, economic and ecological deterioration - local empirical knowledge}

In respect to the social and cultural dimension the collectivist era caused the following damages:

- „automatic employment” and „productivism” as the main characteristics of the state owned agricultural system created bad behavioural patterns in the active generation (passiveness, demotivation, ignorance of cultural and ecological values, loss of entrepreneurial skills);

- as the collectivist era killed the motivation of the potential beneficiaries and as the compensation scheme favoured large, speculative investors, a chaotic land ownership - land use structure was created.

These changes led to the present symptoms of deterioration in the social and cultural dimension, such as the extinction of traditional family farming. The main problem, which seems to be irreversible, is that closely two thirds of the country is suffering heavy rural exodus (motivated, educated and young people are leaving the area). Population decrease in the Koppány Valley is reaching 3\% per year. Mainly young people are leaving the region.

Another serious problem is the lack of knowledge transfer between generations in the villages. The older generation with traditional skills and knowledge is disappearing, the thinking and behavioural patterns of the middle generations were "transformed” by the collectivist era. Thus they are unable to transfer rural heritage to the next generation. On the other hand there is no next generation, school leavers are migrating to towns. Under these circumstances there is a continuous loss of cultural heritage, the remaining spiritual and material folklore is quickly disappearing.

\section{Ecological changes leading to loss of cultural values}

In respect to the ecological dimension collectivism caused major changes, considering the loss of habitats and the rate of homogenization, it is an ecological disaster. 300 hundred years ago these villages were also trading freshwater crabs and turtles, apart from cereals and livestock, which refer to the large proportion of wetlands. Our analysis of the changes in the land use based on the Military Survey Maps made in the $18^{\text {th }}$ and $19^{\text {th }}$ centuries show that $97 \%$ of these wetlands were converted into grazing and arable land.

The socialist cooperative era introduced cereal production oriented interventions in the traditional landscape. They regulated the line and bed of the Koppany stream, straightened and deepened the river bed, with trapezoid cross-section profiles in order to increase the speed of the flow-off. They have also installed a mole drainage system to the stream terraces in order to dry out swampy areas by lowering the water table. The area of intensive crop production based on cereals, maize and sunflower was maximized by turning grazing land, wet or bushy areas, hedges, and smaller forests into arable land, even on slopes steeper than $12 \%$. Small family farm sizes were resized to 50-150 hectares plot sizes to make them suitable for heavy machinery. Intensive use of fertilizers and chemicals has been introduced. 
The main consequences of these major changes included extreme soil degradation. Erosion is so severe in the Koppány Valley that the several meters deep and 15-30 meters long erosion gullies were shown several times in the national public media in 2010 (Figure 3.).



Fig 3. An ephemeral gully formed in the Koppány Valley, Autumn, 2010 (Hungary).

Soil analyses show partial or complete loss of A and/or B horizons of native Ramann type brown forest soils on hillsides, whereas drilled samples show 2-2,5 m sediment accumulated at the bottom of the hills with significant phosphorous content in the deeper layers as the memento of the overdosed cheap Soviet P-fertilizers during the seventies and eighties.

Another serious consequence is the lowered water table, which resulted in the loss of wetland habitats, with their biodiversity and traditional use (reed harvesting, hay-making, hemp rettery pits etc.).

The eroded hillsides and dried up wetlands on the terraces led to excessive runoff and the lack of adequate water retention and infiltration which resulted a disadvantageous water balance and the NP contamination of surface waters in the valley.

Besides ruining the traditional landscape, these interventions reshaped, decreased and fragmented ecological habitats, which led to decreasing biodiversity (extinct local species) and quickly spreading invasive species (Alianthus, Solidago, Asclepias, Amorpha, Acer species) and native weeds.

The 1990s, as a consequence of the dramatic drop in chemical use and re-fragmentation because of the compensation scheme - as it was stopping large scale intensive production, creating small farms -, can be regarded as an interim ecological and landscape "regeneration" period.

In the field of economy, there are only agricultural activities in the valley, which means a company (which is the transformed state cooperative privatised by its former leaders) producing wheat, corn and sunflower on more than $80 \%$ of the arable land, and about 10 families producing the same crops on $80-120$ hectare farms. There is no animal husbandry 
and traditional household production of vegetables, fruits and poultry is disappearing with the old generations, which results in a very low level of self-sufficiency in terms of food.

\section{The lost cultural values in the Koppány Valley}

Land use change, forced collectivization, loss of agri-production knowledge and lack of generation with agricultural background are the main elements of loosing local rural heritage. Most of the traditional agri-cultural values of the Koppány Valley were completely lost (Table 1).

As time passes by, it is difficult to fully reveal former traditions, find photos of cultural values and even more problematic to re-introduce these cultural values into everyday life or for festival events using awareness-raising, education and passing of knowledge. It is important to collect and preserve these material artefacts (Figure 4-6.)

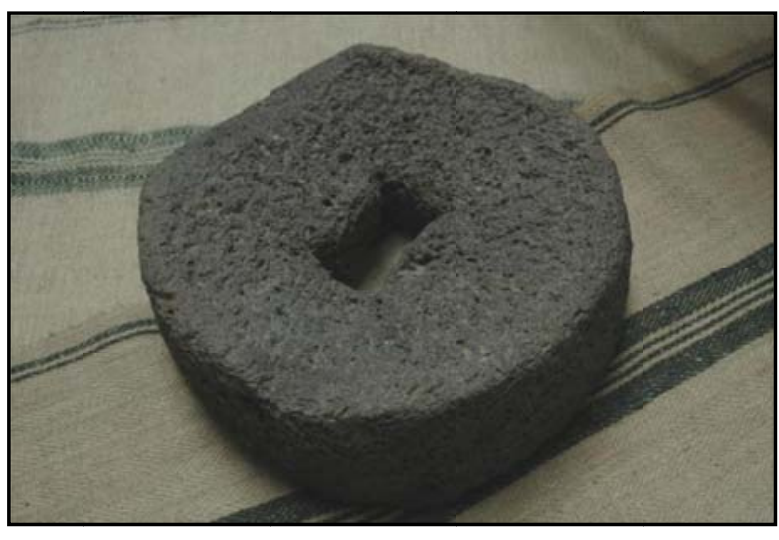

Fig 4. Roman handmill stone, Koppány Valley, Hungary.

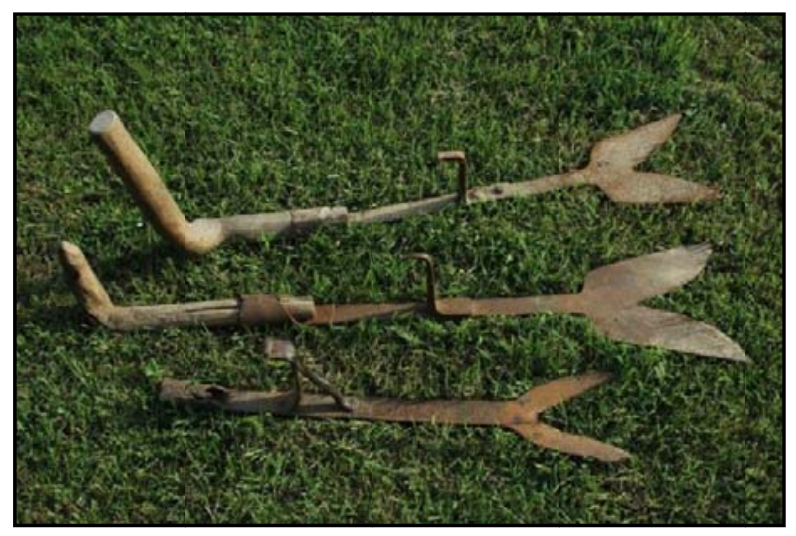

Fig 5. Hay cutters from 19-20 ${ }^{\text {th }}$ century, Koppány Valley, Hungary.

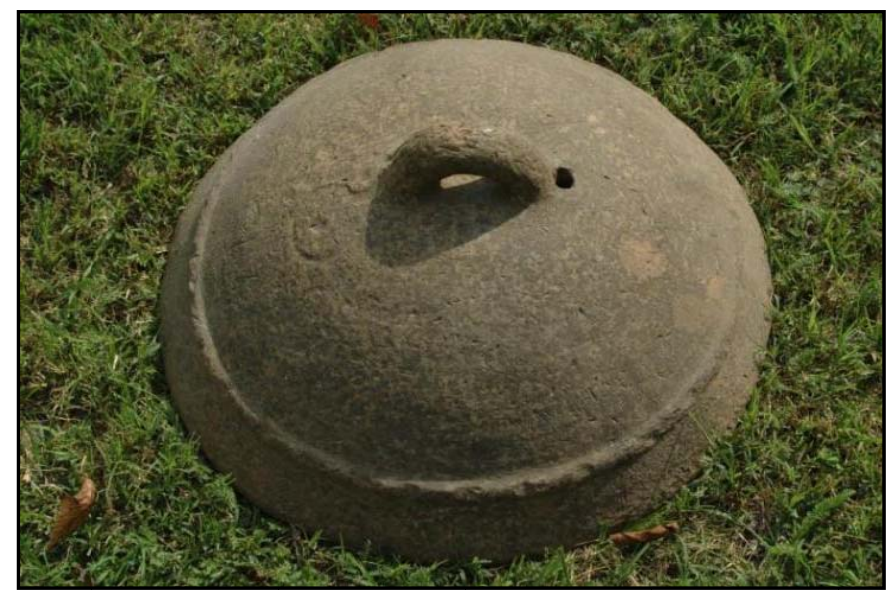

Fig 6. Bread baking bell from the $18^{\text {th }}$ century, Koppány Valley, Hungary. 


\begin{tabular}{|c|c|}
\hline $\begin{array}{c}\text { Missing factors as reason of cultural } \\
\text { heritage loss }\end{array}$ & Results of loosing agri-cultural values \\
\hline $\begin{array}{l}\text { - diversity of the local landscape with } \\
\text { wetlands, pastures, orchards, hedges } \\
\text { and plantations }\end{array}$ & $\begin{array}{l}\text { - loss of wetland related cultural heritage (local building } \\
\text { types, tools, knowledge, transportation by boat etc.), } \\
\text { - loss of animal husbandry related cultural heritage (local } \\
\text { clothing, tools, songs, poems, stories to go around, } \\
\text { foods etc.), } \\
\text { - loss of fruit production related cultural heritage } \\
\text { (local/special buildings, fruit varieties, fruit growing } \\
\text { methods (e.g. pastures with fruit trees etc.), }\end{array}$ \\
\hline - the diversity & $\begin{array}{l}\text { - many local products were important in cultural patterns } \\
\text { of different regions, loosing diversity means loosing } \\
\text { cultural heritage, }\end{array}$ \\
\hline $\begin{array}{l}\text { - the flourishing viticulture and wine } \\
\text { making }\end{array}$ & $\begin{array}{l}\text { - production and consumption of local wines are not } \\
\text { maintained anymore by their traditional cultural roles, }\end{array}$ \\
\hline $\begin{array}{l}\text { - fruit production based on local varieties } \\
\text { and traditional processing methods }\end{array}$ & $\begin{array}{l}\text { - production and consumption of local fruits and fruit } \\
\text { products (e.g. jam, syrup etc) are not maintained any } \\
\text { more by their traditional cultural roles, } \\
\text { - forgetting processing methods means cultural } \\
\text { knowledge and thus cultural heritage loss, }\end{array}$ \\
\hline - tobacco production & $\begin{array}{l}\text { - local tobacco production methods and related cultural } \\
\text { values are lost and seems irreversible because of strict } \\
\text { governmental and EU regulations, }\end{array}$ \\
\hline $\begin{array}{l}\text { - hemp production and processing } \\
\text { methods }\end{array}$ & $\begin{array}{l}\text { - special methods and related cultural values are lost, } \\
\text { however could be re-evaluated, }\end{array}$ \\
\hline $\begin{array}{l}\text { - the once dominating extensive animal } \\
\text { husbandry }\end{array}$ & $\begin{array}{l}\text { - all aspects (cultural, economical, environmental, } \\
\text { landscape ecological, nature conservation etc.) of } \\
\text { disappeared animal husbandry is missing very much, }\end{array}$ \\
\hline - beekeeping & $\begin{array}{l}\text { - it was important as income but its cultural values are } \\
\text { missing (similar reasons like at viticulture and orchards), }\end{array}$ \\
\hline - the traditional mudbrick construction & $\begin{array}{l}\text { - mudbrick played an important role in the society (so its } \\
\text { cultural value is unquestionable) but its ecological } \\
\text { values are just as well missing (e.g. it has very good } \\
\text { insulation characteristics thus no air conditioning } \\
\text { needed and it is constructed from local materials thus } \\
\text { no transportation is needed from hundreds or } \\
\text { thousands of kilometres), seems irreversible because if } \\
\text { strict quality regulations (if someone produce a type of } \\
\text { brick, hundreds of them has to be sent in for quality } \\
\text { check which is impossible in this case), }\end{array}$ \\
\hline - pottery and handicrafts & $\begin{array}{l}\text { - these are the most obviously missing cultural heritage } \\
\text { elements, }\end{array}$ \\
\hline - spiritual folklore & $\begin{array}{l}\text { - some of it is still living but the young generation is } \\
\text { missing since most of them left to other places. }\end{array}$ \\
\hline
\end{tabular}

\section{Sustainable = insufficient? Why is it unfavourable to support rural communities?}

The majority of the nations are coping with increasing its GDP at any cost. As it can be experienced in some Hungarian settlements, almost $100 \%$ of the area is sold for construction sites to fill the holes of the budget. In case we compare different scenarios we can see why politicians and governments are not very keen on supporting rural life (figure 7 , Westhoek et al. 2006).

As we can see on Figure 7, the regional community approach that we are suggesting for the solution of the problems of loosing agricultural heritage is not likely will be supported by decision makers because it ends up with decrease of population (22 million people minus in 30 years). The global economy approach would cause the same increase of the population of EU25. It means more people, more workers, more tax payers etc. 


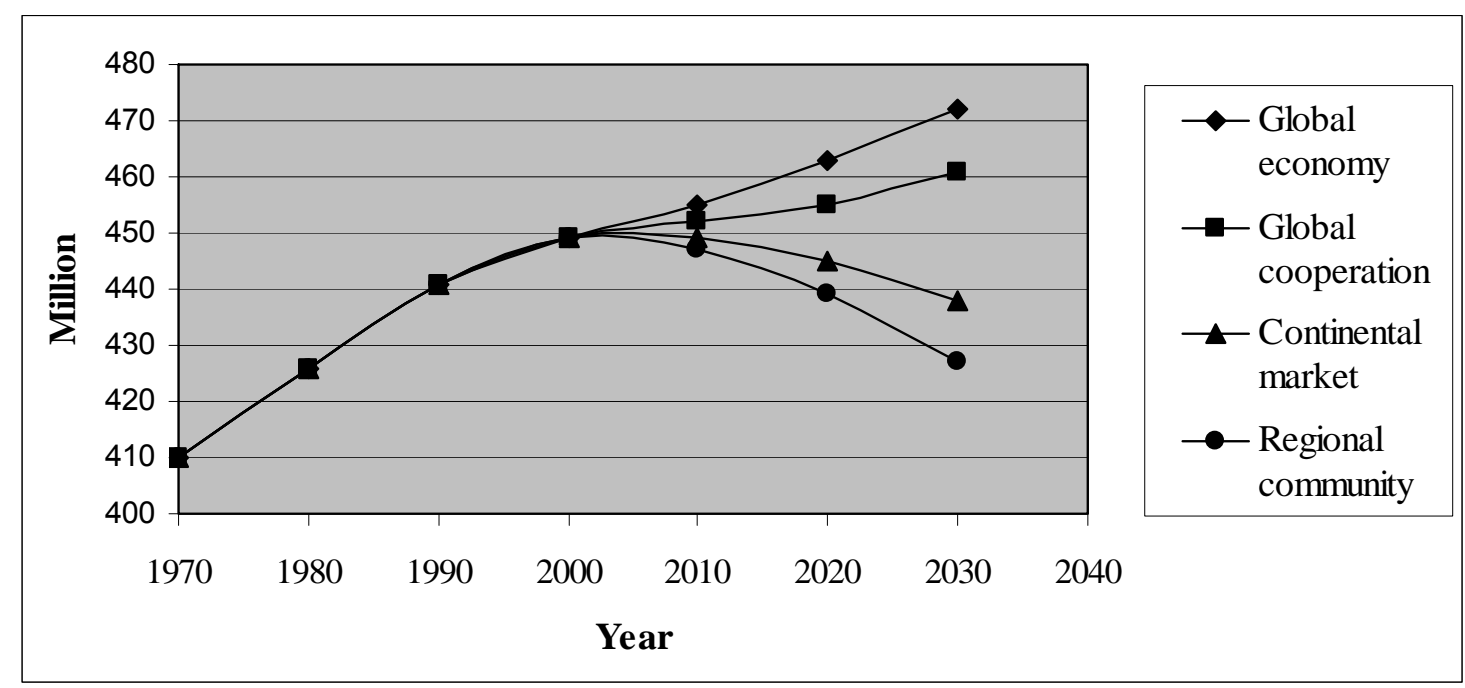

Fig 7. Four demographic scenarios showing the population change in EU25 member states with the storyline of four distinct economical scenarios (Westhoek et al. 2006).

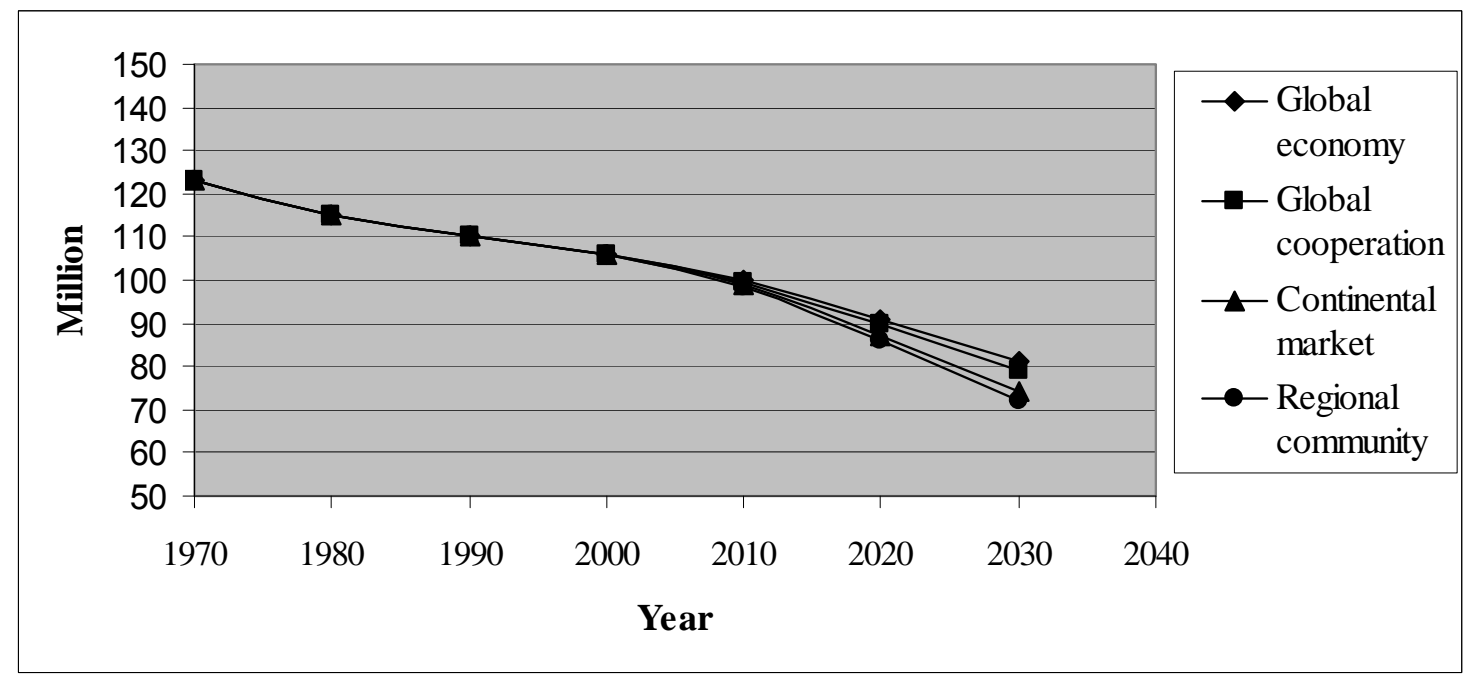

Fig 8. Decrease of rural population with four economical scenarios (Westhoek et al. 2006).

As we can see on figure 8, the population of the rural areas will decrease in any way, although the difference is smaller. While in the scenario for the total area ends up with 44 million people difference between the "Global economy" and the "Regional community" scenarios, in the rural areas and in its population it causes "only" the loss of around 5 million people. Rural population is foreseen as declining in any way.

What is the situation in Hungary? Most of the rural population was forced (in many ways, e.g. economical or political drivers) to move into bigger towns or cities. This created a hotbed for speculations with arable land, forests, water etc. These areas then were acclaimed underdeveloped where business environment is not favourable. It caused the decrease of facilities where rural people could work. Even the local agricultural markets were choked. Thus, the scenario shown on figure 8 reflects what happens on our experimental area. The questions are:

- Is leaving the rural areas the only way for survival?

- Is forcing people to bigger settlements natural or artificial?

- Can there be a better future on rural areas with more jobs, more rural population?

Answering these questions is important because this will answer the question about the survival of rural cultural values! Cultural values were formed by people living in the countryside, their life 
formed and influenced by natural and man made environment. To maintain cultural values active, working and thinking people are needed.

In a study in the UK Keeble et al. (1992) found that rural firms in accessible areas are favourable and can be comparable with urban firms. The authors concluded that accessible rural firms are more dynamic, innovative and technologically focused than their counterparts in either urban or remote rural locations' (Keeble and Tyler 1995). In the Koppány Valley we can also state that the potential is there for a viable environment, e.g. for establishing local business or to provide alternative to big city life and thus avoid further migration to bigger cities as the only possible way.

\section{Conclusion and discussion}

Considering the social circumstances (e.g. rural exodus) the losses of the rural heritage in the Koppány Valley seem to be irreversible, therefore it is important to draw the following conclusions:

- $\quad$ such regions will completely lose their values without external help;

- fresh human resource (immigration) is needed to make any assistance (grants, supports) effective;

- priority should be given to measures enhancing immigration to areas having considerable agricultural heritage and suffering rural exodus,

- ecological reconstruction can be the source of diversity increase and this way to increase cultural heritage through re-introduction or increase of former land use types and related jobs.

Similar rural exodus like in the Koppány Valley has occurred at a larger scale in Europe (Arizpe, 1981). Arizpe (1981) list four great outflows of migrants from Europe between 1844 and 1913. As Arizpe (1981) states: "... was for the most part a rural exodus". However at that time there were 51 million emigrants released mainly from agricultural sector between 1846 and 1932. In the Koppány Valley the numbers of migrants are lower but the result is similar: less people remained in the countryside.

Douglass (1971) examined two Basque villages and found similar situations like we described in the Koppány Valley. According to Douglass (1971), rural depopulation is currently an evident demographic trend in Spanish society. Studies suggest that an entirely economistic interpretation of this rural exodus is in order. As a result farmers (or workers in agriculture) abandon the countryside in response to the greater economic opportunities available in industrial facilities. Douglass (1971) suggests that once the little community is made the unit of study cultural factors other than economic aspirations is likely to influence the agriculturalist's decision-making. This influence can be found in the Koppány Valley as well this is why external help and fresh human support are needed.

Rural exodus is not only a European phenomenon. Shaw (1974) examined the phenomena of rural exodus in Latin America. He found that the reason of rural exodus is the extremely unequal distribution of land in some countries (e.g. Chile, Peru, Bolivia, Mexico) where $60-80 \%$ of all farms belonged to the so called minifundios (and/or landless employee class), representing $0.4-4.0 \%$ of the country's total agricultural land, and an average of 1.0-1.7 ha. Similarities can be found in the Koppány Valley where big agricultural enterprises or re-formed co-operatives are using large areas while other inhabitants having only small parcels and chances of buying further arable land is decreased by big enterprises, partly because prices were artificially increased by their willingness to buy arable land.

Measures can be schemes, supporting the use of technological innovation e.g. for utilizing biomass as protein and/or renewable energy sources and the development of high quality, locally produced and processed niche products (food, herbs etc). These schemes provided have to be integrated into a sustainable local landscape management strategy which allows ecological habitat reconstructions. Habitat reconstruction can be the major source of increasing diversity since all wetland is strictly regulated. The most problematic are the wetlands. There is 
a very little chance to re-formulate, re-construct, re-habilitate former wetlands because of the willingness to remove all excess water as fast as possible from the land.

There is a big potential in ecological habitat reconstruction as it can be seen even on the quite small experimental area, highlighting some fragments with rehabilitation potential (Figure 9).

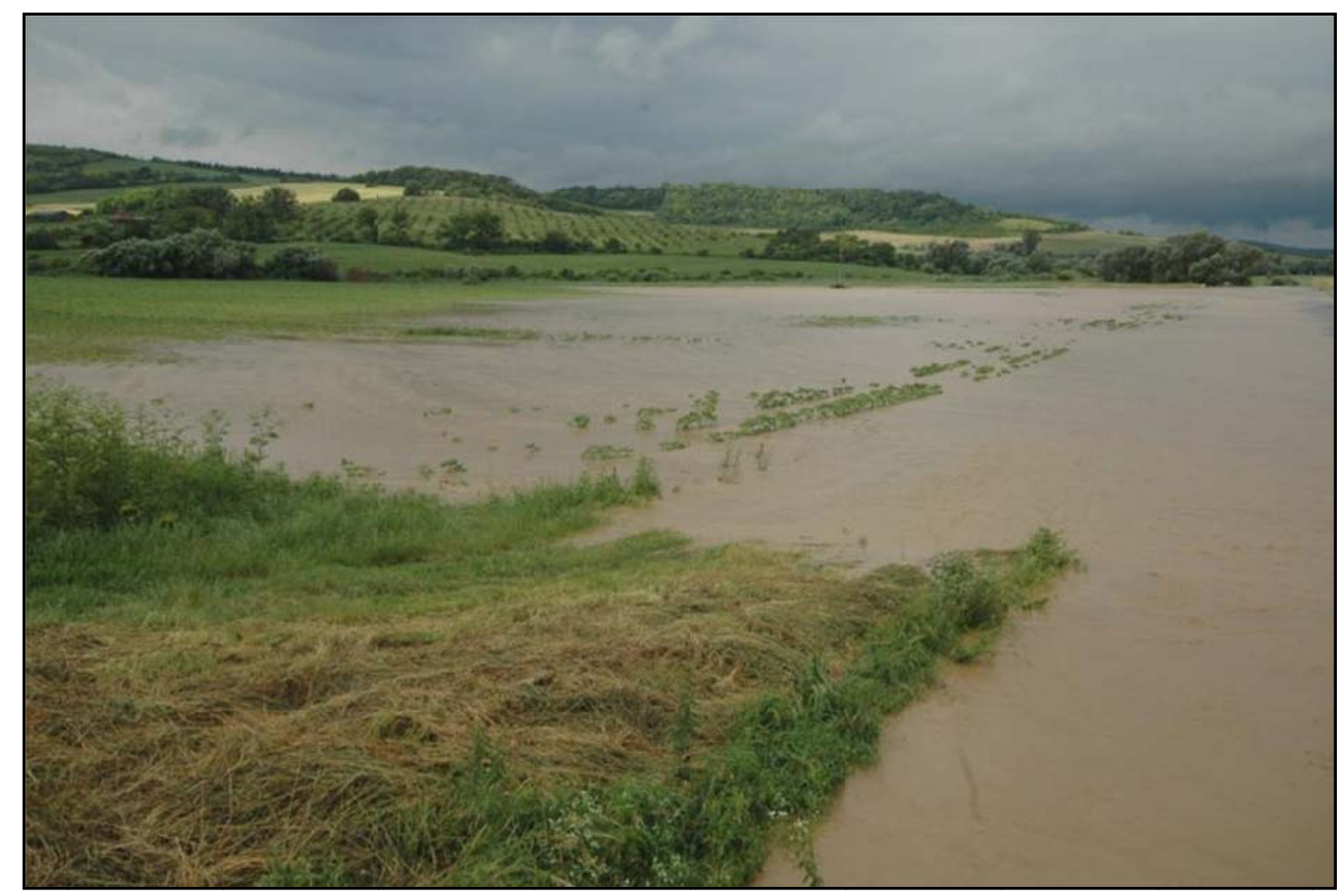

Fig 9. Flooded intensive farming areas along Koppány Creek: Do we need these or shall these be returned to nature? (Koppány Valley, Hungary, 2010).

River regulations suffer the same fate as in other parts of Hungary: too narrow, artificial riverbeds (to maximize arable farmlands); lack of water storage for unexpected flooding events (no farmer wants his land sacrificed for flooding in order to save other people's land or other values); lack of buffer zones at the edge of the river bed (it could be used as water reservoir in case of high floods, for ecological corridors and with wise usage for collecting firewood for local use and to protect surface waters from heavy diffuse contamination originated in fertilizers, from other chemicals (pesticides etc.) and could be the space for collecting sediments from intensive agricultural land.

What solutions can we imagine?

Non-governmental organizations are locally based forces that can help local communities to find solutions for all kinds of problems. Vox Vallis Development Association (VVDA) is an active local community established in 2004 to enhance the evolution of a sustainable agro-ecological system in the area. As the local coordinator of EU rural development funds (LEADER+ and 2007-2013 EU LEADER) VVDA started community mobilization, exploration and conservation of cultural and natural heritage and strengthening income generation potential.

The main activities of VVDA in the field of saving cultural heritage and community development as a possible solution for the problems are as follows:

- review and digital inventory (photos, films, soundtracks, texts) of the local cultural heritage (history, agricultural heritage and folklore);

- develop special curricula for the local schools based on these inventories;

- introduction of teaching traditional sports (archery, "paprika") in the primary schools; 
- assist the interest articulation and representation of the local people by organising participatory development fora;

- developing a local historical and ethnographical collection;

- exploring, collecting and planting local fruit varieties (apple, pear etc.);

- supporting the renovation of old peasant houses and cellars made of "mud-bricks";

- strengthen the civil sphere (creating multi-functional community houses, helping the formation of civil organisations, organising local events etc).

References

[1] Arizpe, L. (1981). The rural exodus in Mexico and Mexican migration to the United States. International Migration Review 15(4), 626-649.

[2] Decree No. 137/2004. (IX. 18.) of the Ministry of Agriculture (2004). Decree of the enactment of the National Rural Development Plan. In: Compex Collection of Operative Laws.

(http://net.jogtar.hu/jr/gen/hjegy_doc.cgi?docid=A0400137.FVM (17/07/2011)).

[3] Douglass, W. A. (1971). Rural Exodus in Two Spanish Basque Villages: A Cultural Explanation. American Anthropologist 73(5), 1100-1114. http://onlinelibrary.wiley.com/doi/10.1525/aa.1971.73.5.02a00090/abstract - fn1. DOI: 10.1525/aa.1971.73.5.02a00090.

[4] Együd, Á. (1975). Somogyi népköltészet. Somogy néprajza 1.

[5] Együd, Á. (1978). Adatok a láncversek számszimbolikájához Kaposvár, 271-310. Somogyi Múzeumok Közleményei 3.

[6] Együd, Á. (1981a). Népi sportszerũ játékok Somogyban (Folk sport-like games in Somogy). Somogyi Múzeumok Közleményei 4: 495-126.

[7] Együd, Á. (1981b). Kaposváron megverték a rézdobot. Száz somogyi népdal. Kaposvár.

[8] Fiar, S. \& Izsák, É. (1997). A föváros természeti környezetének változása- különös tekintettel az urbanizáció tájalakító hatására a XVIII. századtól napjainkig- mintaterületek alapján. In: Füleky, Gy. (Eds.), A táj változásai a Honfoglalás óta a Kárpát-medencében (pp. 223-232). Gödöllő: Gödöllői Agártudományi Egyetem MSZKI.

[9] Gowan, P. (1995). Neo-liberal theory and practice for Eastern Europe. New Left Review 213, 3-60.

[10] Humphrey, C. (2002). The unmaking of Soviet life: everyday economies after socialism. Ithaca: Cornell University Press.

[11] Kapitány, O. \& Imrő, J. (Eds.) (2001). Kaposvár: Somogy Megye Népművészete.

[12] Karcagi-Kovács, A., Odor, K. \& Kuti, I. (2009). The problem of rural exodus in the National Sustainable Development Strategies and National Rural Development Plans of EU members. The Fourth International Scientific Conference, Rural Development 2009 (pp. 208-213).

[13] Keeble, D. \& Tyler, P. (1995). Enterprising behaviour and the urban-rural shift. Urban Studies 32(6): 975-997. Doi: 10.1080/00420989550012753.

[14] Keeble D., Tyler P., Broom G. \& Lewis J. (1992). Business Success in the Countryside: The Performance of Rural Enterprise. London: HMSO.

[15] Mari, I. (1997). A Szentendrei-sziget természeti viszonyainak változása a Honfoglalás óta. In Füleky Gy. (Ed.), A táj változásai a Honfoglalás óta a Kárpát-medencében (pp 233-242). Gödöllö: Gödöllői Agártudományi Egyetem MSZKI. 
[16] Metzger, J. (1997). A tájhasználat alakulása a Vadkerti-tó térségében a XVIII. századtól napjainkig. In: Füleky Gy. (Ed.), A táj változásai a Honfoglalás óta a Kárpát-medencében (409-424). Gödöllö: Gödöllői Agártudományi Egyetem MSZKI.

[17] Molnár, Zs. (1996). Ártéri vegetáció Tiszadob és Kesznyéten környékén I. Tájtörténeti, florisztikai és cönológiai értékelés. Botanikai Közlemények 83(1-2): 39-51.

[18] Nagy, B. (1997). A felszínborítás vizsgálata a Sajó-Hernád hordalékkúp térségében. In: Füleky, Gy. (Ed.) (1997). A táj változásai a Honfoglalás óta a Kárpát-medencében (pp. 391-398). Gödöllő: Gödöllői Agártudományi Egyetem MSZKI.

[19] North, D. \& Smallbone, D. (2000). The innovativeness and growth of rural SMEs during the 1990s. Regional studies 34(2), 145-157. Doi: 10.1080/00343400050006069.

[20] Palang, H., Printsmann, A., Konkoly Gyuró, É., Urbanc, M., Skowronek, E. \& Woloszyn, W. (2006). The Forgotten Rural Landscapes of Central and Eastern Europe. Landscape Ecology 21(3), 347-357., DOI: 10.1007/s10980-004-4313-x.

[21] Pickles, J. \& Smith, A. (eds.) (1998). Theorising Transition: The Political Economy of PostCommunist Transformation. London: Routledge.

[22] Rainnie, A., Smith, A. \& Swain, A. (eds.) (2002). Work, Employment and Transition: Restructuring Livelihoods in Post-Communism. London: Routledge.

[23] Renes, H., Aoun, R., Benito, L., Bojić, M., Buchecker, M., Bulog, J., Centeri, Cs., Dobrovodska, M., Fairclough, G., Grove, D., Martinović-Vuković, Z., Mavar, Z., Ónodi, G., Pető, Á., Printsmann, A., Pungetti, G., Raguž-Lučić, E., Robbiatti, C., Roth, M., Ángeles Ruiz, M., Toma, E., Tóth, V. \& Turner, S. (2010). Chronological development of European agricultural landscapes. In: Pungetti, G. Kruse, A. (eds.) European Culture expressed in Agricultural Landscapes. Perspectives from the Eucaland Project (pp. 83-94). Roma: Palombi Editori.

[24] Rédei, T., Barabás, S., Csecserits, A. \& Kun, A. (1998). A hegylábi löszvegetáció maradványai a Budai-hegységben. Tájtörténeti rekonstrukciós kísérlet. Kitaibelia 3(2), 319-320.

[25] Shaw, R. P. (1974). Land Tenure and the Rural Exodus in Latin America. Economic Development and Cultural Change 23(1), 123-132.

[26] Shaw, R. P. (1975). Land tenure and the rural exodus in Chile, Colombia, Costa Rica, and Peru. Gainesville: University Presses of Florida.

[27] Symes, D. (1993). Agrarian reform and the restructuring of rural society in Hungary. Journal of Rural Studies 9(3), 291-298. Doi:10.1016/0743-0167(93)90073-S.

[28] Szabó, Sz. (2010). Pillanatképek egy dél-dunántúli falu hétköznapjaiból: Törökkoppány. Comitatus - önkormányzati szemle. 20(1-2), 128-151.

[29] Szabó, A. \& Ruprecht, E. (2001). Az Erdélyi- Mezöség közpınti részének fontosabb tájtörténeti és tájdinamikai változásai. Kanitzia 9. 151-164.

[30] Szapu, M. (1999). Children's games in Somogy County. Acta Etnographica Hungarica 44(1-2), 55-77.

[31] Szerényi, J. (2001). Az érd-százhalombattai Sánc-hegy vegetációtörténete a tájtörténet tükrében az őskortól napjainkig. Természetvédelmi Közlemények 9, 87-109.

[32] Tatár, S., Sándor, Cs., Ercsényi, M. \& Milutinovits, L. (2009). Tájtörténeti kutatások a Pesti-síkság északi részén. Tájökológiai Lapok 7(2), 417-442.

[33] Toma, E., Roth, M., Centeri, C., Dobrovodská, M., Printsmann, A. \& Raguž-Lučić, E. (2010). Agricultural landscape history of 20th-century Eastern Europe. In: Pungetti, G. \& Kruse. A. (Eds.), European Culture expressed in Agricultural Landscapes. Perspectives from the Eucaland Project (pp. 105-108). Rome: Palombi Editori. 
[34] Tóth, T. (2001). Tájtörténeti és botanikai kutatások a Felsö-Duna árterületén a NeszmélySüttö közötti Duna-szakaszon. A Puszta 1(18), 141-191.

[35] Tóth, V. (2008). Az Ócsai Tájvédelmi Körzet tájváltozásának természetvédelmi célú vizsgálata. Diplomadolgozat, SzIE, KTI, Gödöllő.

[36] Wascher, D. M. (2004). Landscape-indicator development: steps towards a European approach. In: Jongman, R. H. G. (ed.) Volume 4 The New Dimensions of the European Landscapes (pp. 237-252). Retrieved from

(http://library.wur.nl/ojs/index.php/frontis/article/viewFile/1015/586, access: 17. Jan., 2011).

[37] Westhoek, H. J., van den Berg, M., Bakkes, J. A. (2006). Scenario development to explore the future of Europe's rural areas. Agriculture, Ecosystems and Environment 114:, 7-20., DOI:10.1016/j.agee.2005.11.005. 